\title{
Division Buyout and Refinancing of Event Risk Covenant Bonds: Evidence from the Long-Term Stock Performance
}

\author{
Manish Tewari ${ }^{1}$ \\ ${ }^{1}$ School of Business \& Economics, State University of New York, Brockport, New York, USA \\ Correspondence: Manish Tewari, School of Business \& Economics, State University of New York, 350 New \\ Campus Drive, SUNY, Brockport, NY 14420. USA. Tel: 1-585-395-5678. E-mail: mtewari@brockport.edu
}

Received: March 30, 2013

Accepted: April 27, 2013

Online Published: May 17, 2013

doi:10.5539/ibr.v6n6p1

URL: http://dx.doi.org/10.5539/ibr.v6n6p1

\begin{abstract}
The focus of this paper is to assess the long-term common stock performance of the parent firms that underwent divisional buyout (DBO) and had event risk covenant (ERC) bonds outstanding at the announcement of the DBO. The final sample of 46 parent firms exhibit a common characteristic where all the ERC bonds were redeemed (either called above par or put on the firm at par) or restructured at a higher cost to the firm around DBO announcement date due to the presence of ERCs. ERCs are triggered since the parent firms that divest their assets through a DBO reveal future cash flow volatility, which has potential to lower the value of existing bonds. This refunding of the bonds leads to costly refinancing for the parent firms, which has long-term implications. I find significantly negative cumulative abnormal returns at the issue date of the ERC bonds for these firms due to potential managerial entrenchment and foregone transfer of wealth from bondholders to stockholders. Consistent with the finance literature, I find significantly positive cumulative abnormal returns for parent firms at the announcement of the DBO. These positive short-term returns at the announcement do not translate into long-term positive returns. The common stock of these parent firms significantly underperforms the market over the periods three, four, and five years after the DBO date. This dichotomy can be attributed to the security market overreaction to the announcement of DBO. The long-term underperformance can be attributed to the costly refinancing of the ERC bonds.
\end{abstract}

Keywords: event risk covenants, bonds, division buyout, parent firm, long-term performance

\section{Introduction}

Leveraged buyouts (LBOs) have been widely explored in the finance literature. In an LBO the investors buyout the entire publicly traded firm and take it private primarily with debt financing. Inefficient management and operations have been cited as primary reasons for taking a firm private through a leveraged buyout (Ambrose \& Winters, 1992). Smith (1990) finds that firm's operating performance considerably and significantly increased after the LBO. DeAngelo and DeAngelo (1987) and Kaplan (1989) find that the LBO considerably increases the market value of the target firms at the announcement of LBO.

In a divisional buyout transaction (DBO hereafter), firm's mangers and/or investor(s) buyout a division of a publicly traded firm primarily with debt financing and is typically taken private. Subsequently, the division exists as a separate (new) firm separated from the parent firm which stays public. The net effect of a DBO on the capital structure of the new firm is a substantial increase in the level of debt on the firm's books since the assets of the new firm, including the future cash flows, are used as collateral for the loans obtained in the DBO. The DBOs are motivated by an opportunity to increase the efficient use of assets for the division at the same time improving the effectiveness and efficiency of decision making for the slimmer parent firm (Hite \& Vetsuypens, 1989). The long-term performance of parent firms after the DBO has remained unexplored in the literature. Since, the parent firm stays public after the DBO, the firm's common stock can be observed to evaluate the firm's long-term performance.

Bae and Jo (2002) find that parent firms with high cash flow volatility and high growth are more likely to divest through a DBO. Conversely, parent firms undergoing DBO likely signal volatile future cash flows. Titman and Wessels (1988) and Friend and Lang (1988) find that a firm's ability to raise capital through debt generally decreases with an increase in the volatility of the firm's earnings and cash flow due to the increased risk faced by the bondholders. This increase in risk has potential to lowers the value of outstanding bonds and is likely to 
trigger protective covenants in these bonds. Due to the transfer of wealth from bondholders to stockholders, the lower bond values result into higher returns for the common stockholders. Hite and Vetsuypens (1989) find that the shareholders of the parent firms, undergoing DBO, experience positive and significant wealth effect at the announcement of the DBO.

The event risk covenants (ERCs) in bonds are intended to deter negative wealth effect for the bondholders in the event of a major restructuring of the firm including leveraged and divisional buyouts (Cook \& Easterwood, 1994). These covenants allow bondholders to put the bonds back at par on the firm undergoing these events. Bondholders can use the presence of ERCs in bonds as a bargaining tool and require the firms to restructure and reissue the existing bonds or call the bonds at more favorable terms to bondholders. The ERCs are also commonly referred to as poison puts or super poison puts in finance literature. The ERCs are known to be effective in achieving their intended purpose. Billet, Jiang, and Lie (2010) finds that the bonds with ERCs perform significantly better than the bonds without the ERC protection during a leveraged buyout.

I investigate a sample of 46 parent firms, with non-convertible ERC bonds outstanding, that underwent DBO. I find that all the bonds were either refunded (put back by bondholders or called prematurely) or restructured around the DBO announcement date. This observation is in conformity with the argument by Asquith and Wizman (1990) who state that the bondholders must be appropriately compensated with a premium for the covenant protected bonds that are called due to a buyout since the buyout violates the protective covenants. The ERC protection results in firms refunding the protected bonds at or above premium or restructuring them to the benefit of the bondholders. This refunding leads to a higher refinancing cost for the firm which has long term implications (Chatfield \& Moyer, 1986).

The prime focus of this paper is to study the long-term market performance of the parent firms, with ERC bonds outstanding at the DBO announcement, over the periods three, four, and five years after the DBO. The objective is to study how the refunding of these bonds affects the long-term returns to the common stockholders. Using Fama and French (1993) model, I find that these firms significantly underperform the market in the long-term after the DBO. This result conflicts with the observation of significant positive cumulative abnormal returns around the announcement of the DBO. This dichotomy can be attributed to the short-term exuberance by the investors (Barberis, Shleifer, \& Vishny, 1998). I also find strong evidence of negative cumulative abnormal returns around the issue date of the ERC bonds for these firms. This further confirms the finding by Roth and McDonald (1999) that ERCs in bonds have the potential to induce managerial entrenchment as well as prevent wealth transfer from bondholders to stockholders. These results have important implications for the bond and common stock investors and funds.

\section{Literature Review}

\subsection{DBO and the Parent Firm}

According to Hite and Vetsuypens (1989), the benefit to the parent firms undergoing DBO accrues largely from the improved efficiency and lower complexity of the decision-making for the management of the firm. The expected result after the sale of the division for the parent firm is a smaller, efficient, and more manageable firm. The shareholders of the parent firm, undergoing DBO experience positive wealth effect at the announcement of the DBO (Hite \& Vetsuypens, 1989). In contrast the bondholders of the parent firms are susceptible to a significant loss of wealth due to the transfer of wealth from bondholders to stockholders. Maxwell and Rao (2003) find negative abnormal returns for the bondholders of the firms undergoing divisional divestiture in the announcement month. A significant proportion of the wealth accrued to the stockholders at the DBO announcement results from the losses incurred by the bondholders. Bae and Jo (2002) find that a parent firm with higher volatility of cash flow is more likely to divest a division through a DBO. Hence, a parent firm undergoing DBO is likely to signal high variability of future cash flows consequently, lowering the market value of existing bonds. The parent firms undergoing DBO are categorized as high growth firms with high cash volatility (Bae \& Jo, 2002) in contrast to non-leveraged divestitures such as spin-offs or equity carve-outs where the specific characteristics of the parent firms remain largely unclear.

\subsection{ERC Bonds and Negative Wealth Effect for Common Stockholders}

According to Kahan and Klaussner (1993), ERCs in bonds lower the probability of takeover which can entrench the management. Entrenched management is likely to take actions which may not be in the best interest of the stockholders consequently, increasing the agency cost between the stockholders and managers. This agency problem can lower the stockholder wealth (Shleifer \& Vishny, 1989; Roth \& McDonald, 1999). In addition, the lower probability of takeover effectively reduces the potential of a premium stockholders are likely to earn in the event of a buyout. This premium largely results from the transfer of wealth from bondholders to stockholders. 
This foregone wealth transfer can reduce the stockholder wealth. Perumpral, Davidson, and Sen (1999) attribute negative announcement effect on the stock price to the presence of ERCs in bonds.

\subsection{ERC Bonds and Positive Wealth Effect for Common Stockholders}

The LBOs enable wealth transfer from bondholders to stockholders (Warga \& Welch, 1993; Asquith \& Wizman, 1990; Cook, Easterwood, \& Martin, 1992). Presence of ERCs in bonds effectively limits this transfer of wealth, thereby reducing the potential conflict of interest between the stockholders and bondholders (Myers, 1977; Jensen \& Meckling, 1976). This reduction in the conflict between the stockholders and bondholders potentially reduces the financing cost to the firm since the bondholders are willing to accept lower coupon rate for the lower risk of transfer of wealth (Cremers, Nair, \& Wei, 2007).

\subsection{Effect of Refunding of ERC Bonds Due to the DBO}

All the ERC bonds in our sample of parent firms are redeemed, put back, or restructured around the announcement of DBO date. This action can be attributed to the presence of ERCs in these bonds. In all the instances where the bonds are redeemed (called), they are redeemed at a premium. Since this type of redemption is not optimal (suboptimal) for the firm, it comes at a greater cost. According to $\mathrm{Vu}$ (1986), the firm is willing to pay a premium when the bonds with restrictive covenants are called. This premium is based on the opportunity cost of terms of covenants.

For the bond issues where the terms of the bonds are restructured with new terms more beneficial to the investors, the long-term cost to the firm can be substantial. According to Chatfield and Moyer (1986), the inclusion of a put feature on a bond changes the benefits and costs to the issuer. The issuer enjoys an initially lower anticipated interest cost on the capital raised but faces substantial cost due to the risk of early refunding and a higher interest rate the firm is likely to pay on new bonds to replace (refinance) the issue put back on the firm. Once refunded (suboptimal call or put back), the firm can refinance the bonds only at the higher current market rates. This has potential of substantially increasing long-term financing cost to the parent firm.

\subsection{Long-Term Performance after an Event}

The long-term stock performance after a special event has been well documented in finance literature. Speiss and Affleck-Graves (1999) evaluate the long-term performance of common stock of the firms after the issue of the straight debt. They find strong evidence of negative long-term returns. Affleck-Graves and Miller (2003) study the long-term performance of the firms after the optimal call of the debt. They find evidence of positive long-term returns. Tewariand Ramanlal (2010) study the long-term performance of firms issuing bonds with both call and put options embedded in the bonds. They find strong evidence of higher returns from issue date to the put date but find an evidence of lower returns after the put date.

\section{Hypotheses Development}

Lehn and Poulsen (1991) argue that the ERCs are included in the bonds of the issuers where the risk of the LBO is high. The market's expectations of the parent firm being involved in an LBO or a DBO is expected to be much higher for the parent firm that actually undergoes DBO later. Hence, the market's reaction to the announcement of bond issues with ERCs for these firms (much prior to the DBO) is expected to be negative since forgone wealth transfer and managerial entrenchment far outweigh the benefit of lower agency cost associated with ERCs. This logic formulates hypothesis 1.

H1: The common stock cumulative abnormal returns around the issue date of ERC bonds for these firms should be negative.

Hite and Vetsuypens (1989) find positive abnormal returns for the parent firm at the DBO announcement. They argue that in addition to the premium the parent receives for the divested division, the DBO reduces the complexity of decision making by reducing the diversity of the assets to be managed by the management team. This potentially provides operational benefit to the parent firm. The common stock investors focused on this benefit are likely to bid up the stock price upon the DBO announcement. This argument helps formulate hypothesis 2 .

H2: The common stock cumulative abnormal returns for the parent firm around the announcement of DBO should be positive.

The DBO reveals the riskiness of the future cash flows for the parent firms, which lowers the value of existing debt. The future debt is likely to be issued at a higher cost. ERCs in bonds require parent firms to redeem or restructure these bonds at DBO. The refinancing of these bonds due to the DBO is likely to substantially increase the long-term financing cost to the parent firm. This financing cost is likely to overshadow any operational 
benefit from the sale of the division. The short-term exuberance (positive DBO announcement effect) may not transform into the positive long-term returns (Barberis et al., 1998). All the effects of DBO and the refinancing of the redeemed or restructured ERC bonds on the parent firms are only realized in the long-term. This argument helps formulate hypothesis 3 .

H3: In the long-term, the common stock of the parent firm should underperform after the DBO date.

\section{Sample Selection}

The Securities Data Company Platinum database (SDC Platinum) is used to collect the bond data. The Bloomberg bond data is used to gather details of the terms of redemption of these bonds. The initial sample is collected for all the firms with ERC bond issues after 1986. The year 1986 is chosen as the starting year since that is the historical limit on the Bloomberg bond data. The initial sample is further screened for the ERC bond issuing firms that underwent DBO. The initial sample of firm with ERC bond issues are further screened for the following conditions.

a) At least one year should have elapsed from the issue date to the DBO announcement date in order to eliminate the bonds issued to finance DBO.

b) The cutoff date for the sample parent firms is set as 2007 since the objective is to measure the long-term performance over the period five years after the DBO announcement date.

c) The issuing firm must be listed on a US exchange.

d) The stock prices must be available on the Center for Research in Security Prices (CRSP) database.

The firms are further screened on Bloomberg to determine if the ERC protected bond issue was called, put, or restructured and the terms of restructure. The final full sample consists of 46 issues of the parent firms that underwent DBO and had ERC bonds outstanding that were redeemed or restructured around the DBO date.

\section{Research Methods}

\subsection{Short-Term Event Study (Announcement Effect)}

\subsubsection{Fama-French Model}

The focus of this study is to examine the determinants of cumulative abnormal return on the common stock of the firms over the event period. The abnormal returns are estimated using the Fama and French (1993) three-factor model (F-F hereafter) with a pre-event estimation window of $[-255,-46]$ trading days prior to the event date. The F-F model is represented by the equation 1 below:

$$
\left(R_{i t}-R_{f t}\right)=\alpha_{i}+\beta_{i}\left(R_{m t}-R_{f t}\right)+s_{i} S M B_{t}+h_{i} H M L_{t}+\varepsilon_{i t}
$$

Where,

$R_{f t}=$ the risk free rate.

$R_{i t}=$ the daily return of the stock $i$ on day $t$.

$R_{m t}=$ the return on the CRSP value-weighted index on day $t$.

$S M B_{t}=$ the return on the mimicking portfolio for size (Small minus Big) on day $t$.

$H M L_{t}=$ the return on the mimicking portfolio for book-to-market (High minus Low).

The values and details of the construction of the variables $R_{m t}, R_{f t}, S M B_{t}$, and $H M L_{t}$ are obtained from the Kenneth French website.

Equation 1 defines the relationship between the stock returns and the market during the pre-event estimation period $[-255,-46]$. Regression analysis using equation 1 is used to predict the expected daily returns for a given stock on a given day using CRSP value-weighted index on that day. The expected return ( $\hat{R}_{i t}$ ) for a stock ion day $t$ is represented by equation 2 below:

$$
\left(\hat{R}_{i t}-R_{f t}\right)=\hat{\alpha}_{i}+\hat{\beta}_{i}\left(R_{m t}-R_{f t}\right)+\hat{s}_{i} S M B_{t}+\hat{h}_{i} H M L_{t}+\hat{\varepsilon}_{i t}
$$

The event study captures the effect of some unexpected new information on the firms' stock prices. The abnormal return is calculated for each day by subtracting the firm's expected stock return (i.e. the return you would expect given its beta or association with the F-F value weighted overall stock market return over the 255 days prior to the event) from the actual observed return (MacKinlay, 1997).

For each firm the daily abnormal return $\left(A R_{i t}\right)$ and the cumulative abnormal return (CAR) are calculated in the event window for examining the extent to which the stocks responds to the event. The $A R_{i t}$ is calculated by 
equation 3 below:

$$
A R_{i t}=R_{i t}-\hat{R}_{i t}
$$

Where $R_{i t}$ is the actual return on stock $i$ on day $t$ in the event window.

The CAR is calculated using equation 4 :

$$
\operatorname{CAR}_{(t 2, t 1)}=\sum_{t 1}^{t 2} A R_{t}
$$

Where $t 1$ and $t 2$ represent beginning and the end of the three day trading window, $t \in(t 1, t 2)$.

\subsubsection{Market Model}

The results for abnormal results are also obtained using the market model in order to check the robustness of results from the F-F model.

The market model uses the equation 5:

$$
\left(R_{i t}-R_{f t}\right)=\alpha_{i}+\beta_{i}\left(R_{m t}-R_{f t}\right)+\varepsilon_{i t}
$$

The expected return over the estimation period $[-255,-46]$ is computed using equation 6 :

$$
\left(\hat{R}_{i t}-R_{f t}\right)=\hat{\alpha}_{i}+\hat{\beta}_{i}\left(R_{m t}-R_{f t}\right)+\hat{\varepsilon}_{i t}
$$

The abnormal return is computed using equation 3 and the CAR is computed using equation 4 .

\subsubsection{Event Study at the Issue Date}

This study uses issue date rather than the announcement date for the bond sample to measure abnormal returns around the issue date. According to Harvey, Lins, and Roper (2004), the announcement date for a typical bond issue almost always occurs either on the issue date or after the issue date. Even in the cases where the announcement is made prior to the issue date, market is unsure whether the issue will actually take place. In addition, the details of the contract parameters of the bonds are not revealed until the issue is registered. Therefore, the event window $(0,+3)$ is primarily used to fully capture the reaction of the market after the details of the debt issue are fully digested by the market. Results for the windows $(0,+1)$ and $(0,+2)$ are also provided to observe the momentum of abnormal returns.

\subsubsection{Event Study at DBO Announcement}

The abnormal returns are measured around the DBO announcement date with expectations that the market is likely to react very sharply to the DBO news. A DBO announcement is likely to produce highest abnormal returns over the $(0,+1)$ window, which is the primary window of focus in this study. The results for the other windows $(-1,+2)$ and $(0,+3)$ are also provided. The $(-1,+2)$ is chosen in order to capture the abnormal returns just in case the DBO news was leaked a trading day prior to the announcement date. The $(0,+2)$ window is used to test whether the momentum of abnormal returns continued for a trading day longer.

\subsection{Long-Term Event Study}

The long-term study to examine the long-run performance of the common stock of the 46 parent firms that underwent DBO also uses F-F regression method. The fourth factor commonly known as momentum factor (Brav, Geczy, \&Gompers, 2000) is included to account for the presence of any momentum in the return. Since the objective is to measure the long-term monthly returns after the DBO announcement date, the common stock returns are examined over the periods three, four, and five years after the DBO announcement date.

The four factor model used to determine the long run performance is represented by equation 7 :

$$
\left(R_{p t}-R_{f t}\right)=\alpha+\beta\left(R_{m t}-R_{f t}\right)+s\left(S M B_{t}\right)+h\left(H M L_{t}\right)+u\left(U M D_{t}\right)+\varepsilon_{t}
$$

Where,

$R_{p t}=$ the return on the portfolio of sample firms in month $t$. It is calculated using the calendar time average method where each month's returns represent the monthly average for each stock's return that falls in that month (Mitchell \& Stafford, 2000). The portfolio of firms is formed for each month that falls in the event period and monthly portfolio returns are calculated beginning from the month when the DBO announcement is made and continues over the event period.

$U M D_{t}=$ the momentum factor.

The explanation of variables $R_{m t}, R_{f t}, S M B_{t}$, and $H M L_{t}$ is provided in section 5.1.1. The value and the details of construction of $U M D_{t}$ are obtained from the Kenneth French website.

The primary focus in the long-term studies is on the intercept term $\alpha$, which captures the abnormal returns per 
month. The monthly average returns $\left(R_{p t}\right)$ are calculated by constructing value-weighted (VW) portfolio. The portfolio is constructed by taking weighted average of the returns of all the firms that fall in a particular month, weighted by the firm value (market capitalization) (Fama \& French, 1993). The results are presented for the ordinary least squares (OLS) regression method. The results are also presented for the weighted least squares (WLS) regression method to check the robustness of the results.

\section{Results}

Table 1 depicts the CAR over the windows $(0,+3),(0,+2)$, and $(0,+1)$ around the ERC bonds issue date. These results are provided to test the hypothesis 1 . The results for F-F model as well as the market model are presented for the equally weighted/value weighted CRSP index. The focus is on the results over the event window $(0,+3)$ as discussed earlier in section 5.1.3. For the F-F equally weighted model the CAR is $-1.26 \%$ and statistically significant at $5 \%$. For the F-F value weighted model the CAR is $-1.29 \%$ and is statistically significant at $5 \%$. The CAR for the equally weighted and the value weighted market model is also negative and statistically significant at $5 \%$. The CAR for $(0,+2)$ and $(0,+1)$ is also negative and statistically significant for both equally weighted and value weighted F-F and the market model. These results confirm our hypothesis 1.

Table 1. Mean cumulative abnormal returns (CAR) around the ERC bonds issue date

\begin{tabular}{llllll}
\hline Method & $\begin{array}{l}\text { Event Window } \\
\text { (Days) }\end{array}$ & $\begin{array}{l}\text { Mean Cumulative } \\
\text { Abnormal Return }\end{array}$ & $\begin{array}{l}\text { Portfolio Time-Series } \\
\text { t-statistic }\end{array}$ & $\begin{array}{l}\text { Percent } \\
\text { Negative }\end{array}$ & $\begin{array}{l}\text { Generalized } \\
\text { Sign Z }\end{array}$ \\
\hline Fama-French/Equally & $(0,+1)$ & $-0.80 \%$ & $-1.62^{*}$ & 63 & $-1.29^{*}$ \\
Weighted & $(0,+2)$ & $-1.10 \%$ & $-1.81^{* *}$ & 58 & $-1.86^{* *}$ \\
& $(0,+3)$ & $-1.26 \%$ & $-1.81^{* *}$ & 61 & $-2.06^{* *}$ \\
\hline Fama-French/Value & $(0,+1)$ & $-0.77 \%$ & $-1.55^{*}$ & 59 & -0.83 \\
Weighted & $(0,+2)$ & $-1.12 \%$ & $-1.84^{* *}$ & 68 & $-2.01^{* *}$ \\
& $(0,+3)$ & $-1.29 \%$ & $-1.84^{* *}$ & 65 & $-1.71^{* *}$ \\
\hline Market Model/Equally & $(0,+1)$ & $-0.86 \%$ & $-1.67^{* *}$ & 66 & $-1.55^{*}$ \\
Weighted & $(0,+2)$ & $-1.25 \%$ & $-2.00^{* *}$ & 68 & $-1.88^{* *}$ \\
& $(0,+3)$ & $-1.43 \%$ & $-1.97^{* *}$ & 68 & $-1.88^{* *}$ \\
\hline Market Model/Value & $(0,+1)$ & $-0.78 \%$ & $-1.51^{*}$ & 66 & $-1.69^{* *}$ \\
Weighted & $(0,+2)$ & $-1.03 \%$ & $-1.64^{* *}$ & 61 & -1.04 \\
& $(0,+3)$ & $-1.25 \%$ & $-1.71^{* *}$ & 63 & $-1.36^{*}$ \\
\hline
\end{tabular}

Description: The results show average cumulative abnormal returns for the event windows $(0,+1),(0,+2)$, and $(0,+3)$. $(+1),(+2)$, and $(+3)$ correspond to the first, second, and third trading day after the issue date respectively. Abnormal returns are estimated using returns from 255 days prior to the issue date and ending 46 days before the issue date. The significance of the difference between the proportion of positive/negative returns in the event period and the fraction of positive/negative returns in the estimation period is measured by Generalized Sign $\mathrm{Z}$ test. $* * *, * *$, and $*$ indicate significance at the $1 \%, 5 \%$, and $10 \%$ level, respectively.

Table 2 depicts the CAR over the windows $(-1,+2),(0,+1)$, and $(0,+2)$ around the DBO announcement date. These results are provided to test the hypothesis 2 . The results for F-F model as well as the market model are presented for the equally weighted/value weighted CRSP index. The focus is on the results over the event window $(0,+1)$ as discussed earlier in section 5.1.4. For the F-F equally weighted model the CAR is $4.66 \%$ and statistically significant at $1 \%$. For the F-F value weighted model the CAR is $4.78 \%$ and is statistically significant at $1 \%$. The CAR for the equally weighted and the value weighted market model is also positive and statistically significant at $1 \%$. The CAR for $(-1,+2)$ and $(0,+2)$ is also positive and statistically significant at $1 \%$ for both equally weighted and value weighted, F-F and the market models. These results confirm our hypothesis 2. 
Table 2. Mean cumulative abnormal returns around the DBO announcement date

\begin{tabular}{|c|c|c|c|c|c|}
\hline Method & $\begin{array}{l}\text { Event Window } \\
\text { (Days) }\end{array}$ & $\begin{array}{l}\text { Mean Cumulative } \\
\text { Abnormal Return }\end{array}$ & $\begin{array}{l}\text { Portfolio Time-Series } \\
\text { t-statistic }\end{array}$ & $\begin{array}{l}\text { Percent } \\
\text { Positive }\end{array}$ & $\begin{array}{l}\text { Generalized } \\
\text { Sign } \mathrm{Z}\end{array}$ \\
\hline Fama-French/Equally & $(-1,+2)$ & $4.77 \%$ & $5.245^{* * *}$ & 68 & $2.418 * * *$ \\
\hline \multirow[t]{2}{*}{ Weighted } & $(0,+1)$ & $4.66 \%$ & $7.246 * * *$ & 70 & $2.747 * * *$ \\
\hline & $(0,+2)$ & $4.61 \%$ & $5.844 * * *$ & 65 & $2.088 * *$ \\
\hline Fama-French/Value & $(-1,+2)$ & $4.96 \%$ & $5.436 * * *$ & 68 & $2.418 * * *$ \\
\hline \multirow[t]{2}{*}{ Weighted } & $(0,+1)$ & $4.78 \%$ & $7.411 * * *$ & 76 & $3.405 * * *$ \\
\hline & $(0,+2)$ & $4.75 \%$ & $6.013 * * *$ & 65 & $2.088 * *$ \\
\hline Market Model/Equally & $(-1,+2)$ & $4.07 \%$ & $4.317 * * *$ & 59 & $1.667 * *$ \\
\hline \multirow[t]{2}{*}{ Weighted } & $(0,+1)$ & $4.21 \%$ & $6.322 * * *$ & 65 & $2.327 * * *$ \\
\hline & $(0,+2)$ & $4.03 \%$ & $4.931 * * *$ & 62 & $1.997 * *$ \\
\hline Market Model/Value & $(-1,+2)$ & $4.41 \%$ & $4.671 * * *$ & 65 & $1.455^{*}$ \\
\hline \multirow[t]{2}{*}{ Weighted } & $(0,+1)$ & $4.41 \%$ & $6.603 * * *$ & 62 & $2.113 * *$ \\
\hline & $(0,+2)$ & $4.37 \%$ & $5.353 * * *$ & 61 & $1.784 * *$ \\
\hline
\end{tabular}

Description: The results show average cumulative abnormal returns for the event windows $(-1,+2),(0,+1)$, and $(0,+2)$. The days in the windows correspond to a day prior $(-1)$ to the DBO announcement date $(0)$ and the first $(+1)$, and the second $(+2)$ trading day after the DBO announcement date. Abnormal returns are estimated using returns from 255 days prior to the DBO announcement date and ending 46 days before the DBO announcement date. The significance of the difference between the proportion of positive/negative returns in the event period and the fraction of positive/negative returns in the estimation period is measured by Generalized Sign $\mathrm{Z}$ test. ***,**, and * indicate significance at the $1 \%, 5 \%$, and $10 \%$ level, respectively.

Table 3 provides the results for the calendar time average F-F model (with momentum factor) for the sample of 46 firms. These results are provided to test the hypothesis 3 . The panels A, B, and C in table 3 provide the OLS and WLS results for the VW portfolios over the periods three, four, and five years after the DBO announcement date. The focus in the long-term type event studies is on the intercept estimate $\alpha$, which measures the abnormal monthly return. The $\alpha$ for the event period from issue date to three years after the issue date (Panel A) shows negative monthly return of $-0.83 \% /-0.75 \%$ for OLS/WLS methods, statistically significant at $5 \%$. These monthly returns compound to a significant loss of $-26 \% /-24 \%$ over the entire three year period. The $\alpha$ for the event period from issue date to four years after the issue date (Panel B) shows negative monthly return of $-0.62 \% /-0.58 \%$ for OLS/WLS methods, statistically significant at $10 \%$ and $5 \%$ respectively. These monthly returns compound to a significant loss of $-26 \% /-24 \%$ over the entire four year period. The $\alpha$ for the event period from issue date to five years after the issue date (Panel C) shows negative monthly return of $-0.51 \% /-0.60 \%$ for OLS/WLS methods, statistically significant at $10 \%$ and $5 \%$ respectively. These monthly returns compound to significant loss of $-26 \% /-30 \%$ over the entire five year period. All the results provide strong evidence that these firms significantly underperform three, four, and five years after the DBO date. These results confirm hypothesis 3.

Table 3. Long-term performance after the DBO announcement date

\begin{tabular}{|c|c|c|c|c|c|c|}
\hline Event Period & $\alpha$ & $\beta$ & $\mathrm{s}$ & $\mathrm{h}$ & $\mathrm{u}$ & $\operatorname{AdjR}^{2}$ \\
\hline \multicolumn{7}{|c|}{ Panel A: 3 Year Returns } \\
\hline OLS Regression & $\begin{array}{l}-0.83 \\
(-2.03)^{* *}\end{array}$ & $\begin{array}{l}1.11 \\
(11.93)^{* * *}\end{array}$ & $\begin{array}{l}0.49 \\
(3.90)^{* * *}\end{array}$ & $\begin{array}{l}0.50 \\
(3.05)^{* * *}\end{array}$ & $\begin{array}{l}-0.16 \\
(-2.63)^{* * *}\end{array}$ & $39.90 \%$ \\
\hline WLS Regression & $\begin{array}{l}-0.75 \\
(-1.96) * *\end{array}$ & $\begin{array}{l}1.04 \\
(11.36)^{* * *}\end{array}$ & $\begin{array}{l}0.53 \\
(5.00)^{* * *}\end{array}$ & $\begin{array}{l}0.50 \\
(4.02)^{* * *}\end{array}$ & $\begin{array}{l}-0.21 \\
(-3.02)^{* * *}\end{array}$ & $36.76 \%$ \\
\hline \multicolumn{7}{|c|}{ Panel B: 4 Year Returns } \\
\hline OLS Regression & $\begin{array}{l}-0.62 \\
(-1.59)^{*}\end{array}$ & $\begin{array}{l}1.13 \\
(12.69)^{* * *}\end{array}$ & $\begin{array}{l}0.50 \\
(4.06)^{* * *}\end{array}$ & $\begin{array}{l}0.41 \\
(2.58)^{* * *}\end{array}$ & $\begin{array}{l}-0.08 \\
(-2.69)^{* * *}\end{array}$ & $42.38 \%$ \\
\hline WLS Regression & $\begin{array}{l}-0.58 \\
(-1.67)^{* *}\end{array}$ & $\begin{array}{l}1.04 \\
(12.41)^{* * *}\end{array}$ & $\begin{array}{l}0.45 \\
(4.70)^{* * *}\end{array}$ & $\begin{array}{l}0.35 \\
(3.04)^{* * *}\end{array}$ & $\begin{array}{l}-0.28 \\
(-2.48)^{* * *}\end{array}$ & $41.09 \%$ \\
\hline \multicolumn{7}{|c|}{ Panel C: 5 Year Returns } \\
\hline OLS Regression & $\begin{array}{l}-0.51 \\
(-1.47)^{*}\end{array}$ & $\begin{array}{l}1.15 \\
(13.46)^{* * *}\end{array}$ & $\begin{array}{l}0.45 \\
(3.70)^{* * *}\end{array}$ & $\begin{array}{l}0.43 \\
(2.80)^{* *}\end{array}$ & $\begin{array}{l}-0.18 \\
(-3.22)^{* * *}\end{array}$ & $49.03 \%$ \\
\hline WLS Regression & $\begin{array}{l}-0.6 \\
(-1.91)^{* *}\end{array}$ & $\begin{array}{l}1.07 \\
(14.17)^{* * *}\end{array}$ & $\begin{array}{l}0.43 \\
(5.05)^{* * *}\end{array}$ & $\begin{array}{l}0.44 \\
(4.30)^{* * *}\end{array}$ & $\begin{array}{l}-0.09 \\
(-3.11)^{* * *}\end{array}$ & $46.49 \%$ \\
\hline
\end{tabular}

Description: OLS corresponds to Ordinary Least Squares regression. WLS corresponds to Weighted Least Squares regression. Value weighted returns are used for both OLS and WLS methods where the returns are weighted by the market capitalization of the firm at the DBO announcement date. White's method (White, 1980) is used to calculate t-statistics. *** indicates significance at $1 \%$ level, ** indicates significance at $5 \%$ level, and $*$ indicates significance at $10 \%$ level. 


\section{Conclusion}

The protective provisions, such as ERCs in bonds, intended to provide protection to the bondholders from significant firm restructuring events such as leveraged buyout (LBO) and divisional buyout (DBO) typically, require the issuing (parent) firms to redeem (make suboptimal call or put back by investors) or restructure these bonds and reissue with terms favorable to the investors and unfavorable to the firms. Refinancing of redeemed issues places long-term cost burden on the parent firm (Chatfield \& Moyer, 1986). Although, DBO is expected to provide operational benefits to the parent firm (Hite \& Vetsuypens, 1989), the parent firms with ERC bonds outstanding are likely to face enormous long-term refinancing cost of these bonds. In analyzing the long-term performance of a sample of 46 parent firms with DBO that had ERC bonds outstanding at the DBO, I find that the refinancing cost of ERC protected bonds overshadows any operational benefits of the DBO. These firms significantly underperform the market in the long-term over the periods three, four, and five years after the DBO. I also find strong evidence of short-term positive announcement effect at the announcement of the DBO for these parent firms. The short-term positive abnormal returns at the DBO announcement do not transform into long-term positive returns. This dichotomy can be attributed to short-term overreaction by the common stock investors (Barberis et al., 1998). I also find significantly negative cumulative abnormal returns at the issue date of the ERC bonds by the parent firms. This confirms the observation by (Perumpral et al., 1999; Billet et al., 2010) that the presence of ERCs in bonds lowers the stock price due to managerial entrenchment and potential loss of restructure premium for the stockholders. These results have significant implications for the bond investors and common stock investors in these types of firms.

\section{References}

Affleck-Graves, J., \& Miller, R. E. (2003). The Information Content of Calls of Debt: Evidence from Long-Run Stock Returns. Journal of Financial Research, 26(4), 421-447. http://dx.doi.org/10.1111/1475-6803.00067

Ambrose, B. W., \& Winters, D. B. (1992). Does an Industry Effect Exists for Leveraged Buyouts? Financial Management, 21(1), 89-101. http://dx.doi.org/10.2307/3665683

Asquith, P., \& Wizman, T. A. (1990). Event Risk, Covenants, and Bondholder Returns in Leveraged Buyouts. Journal of Financial Economics, 27(1), 195-213. http://dx.doi.org/10.1016/0304-405X(90)90026-V

Bae, S. C., \& Jo, H. (2002). Consolidating Corporate Control: Divisional Versus Whole-Company Leveraged Buyouts. Journal of Financial Research, 25(2), 247-262. http://dx.doi.org/10.1111/1475-6803.t01-1-00006

Barberis, N., Shleifer, A., \& Vishny, R. (1998). A Model of Investor Sentiment. Journal of Financial Economics, 49(3), 307-343. http://dx.doi.org/10.1016/S0304-405X(98)00027-0

Billett, M. T., Jiang, Z., \& Lie, E. (2010). The Effect of Change-in-Control Covenants on Takeovers: Evidence from Leveraged Buyouts. Journal of Corporate Finance, 16(1), 1-15. http://dx.doi.org/10.1016/j.jcorpfin.2009.09.005

Brav, A., Geczy, C., \& Gompers, P. (2000). Is the Abnormal Return Following Equity Issuance Anomalous? Journal of Financial Economics, 56(2), 209-249. http://dx.doi.org/10.1016/S0304-405X(00)00040-4

Chatfield, R. E., \& Moyer, R. C. (1986). "Putting" Away Bond Risk: An Empirical Examination of the Value of the Put Option on Bonds. Financial Management, 15(2), 26-33. http://dx.doi.org/10.2307/3664975

Cook, D. O., \& Easterwood, J. C. (1994). Poison Put Bonds: An Analysis of their Economic Role. Journal of Finance, 49(5), 1905-1920. http://dx.doi.org/10.1111/j.1540-6261.1994.tb04787.x

Cook, D. O., Easterwood, J. C., \& Martin, J. (1992). Bondholder Wealth Effects of Management Buyouts. Financial Management, 21(1), 102-113. http://dx.doi.org/10.2307/3665684

Cremers, M. K. J., Nair, V. B., \& Wie, C. (2007). Governance Mechanisms and Bond Prices. Review of Financial Studies, 20(5), 1359-1388. http://dx.doi.org/10.1093/revfin/hhm006

DeAngelo, H., \& DeAngelo, L. (1987). Management Buyouts of Publicly Traded Corporations. Financial Analysts Journal, 43(3), 38-49. http://dx.doi.org/10.2469/faj.v43.n3.38

Fama, E., \& French, K. (1993). Common Risk Factors in the Returns on Stocks and Bonds. Journal of Financial Economics, 33(1), 3-56. http://dx.doi.org/10.1016/0304-405X(93)90023-5

Friend, I., \& Lang, L. P. (1988). An Empirical Test of the Impact of Managerial Self-interest on Corporate $\begin{array}{lllll}\text { Capital Structure. } & \text { Journal }\end{array}$ http://dx.doi.org/10.1111/j.1540-6261.1988.tb03938.x

Harvey, C. R., Lins, K. V., \& Roper, A. H. (2004). The Effect of Capital Structure When Expected Agency Costs 
are Extreme. Journal of Financial Economics, 74(1), 3-30. http://dx.doi.org/10.1016/j.jfineco.2003.07.003

Hite, G. L., \& Vetsuypens, M. R. (1989). Management Buyouts of Divisions and Shareholder Wealth. Journal of Finance, 44(4), 953-970. http://dx.doi.org/10.1111/j.1540-6261.1989.tb02632.x

Jensen, M. C., \& Meckling, W. H. (1976). Theory of the Firm: Managerial Behavior, Agency Costs, and Ownership Structure. Journal of Financial Economics, 3(4), 305-360. http://dx.doi.org/10.1016/0304-405X(76)90026-X

Kahan, M., \& Klausner, M. (1993). Antitakeover Provisions in Bonds: Bondholder Protection or Management Entrenchment? UCLA Law Review, 40(1), 931-982.

Kaplan, S. (1989). The Effects of Management Buyouts on Operating Performance and Value. Journal of Financial Economics, 24(2), 217-254. http://dx.doi.org/10.1016/0304-405X(89)90047-0

Lehn, K., \& Poulsen, A. (1991). Contractual Resolution of Bondholder-Stockholder Conflicts in Leveraged Buyouts. Journal of Law and Economics, 34(2), 645-673. http://dx.doi.org/10.1086/467238

MacKinlay, C. A. (1997). Event Studies in Economics and Finance. Journal of Economic Literature, 35(1), 13-39.

Maxwell, W. F., \& Rao, R. P. (2003). Do Spin-offs Expropriate Wealth from Bondholders? Journal of Finance, 58(5), 2087-2108. http://dx.doi.org/10.1111/1540-6261.00598

Mitchell, M., \& Stafford, E. (2000). Managerial Decisions and Long-Term Stock Price Performance. Journal of Business, 73(3), 287-329. http://dx.doi.org/10.1086/209645

Myers, S. C. (1977). Determinants of Corporate Borrowing. Journal of Financial Economics, 5(2), 147-175. http://dx.doi.org/10.1016/0304-405X(77)90015-0

Perumpral, S., Davidson, D., \& Sen, N. (1999). Event Risk Covenants and Shareholder Wealth: Ethical Implications of the "Poison Put" Provision in Bonds. Journal of Business Ethics, 22(2), 119-132. http://dx.doi.org/10.1023/A:1006091829986

Roth, G., \& McDonald, C. G. (1999). Shareholder-Management Conflict and Event Risk Covenants. Journal of Financial Research, 22(2), 207-225.

Shleifer, A., \& Vishny, R. W. (1989). Management Entrenchment: The Case of Manager-Specific Investments. Journal of Financial Economics, 25(1), 123-139. http://dx.doi.org/10.1016/0304-405X(89)90099-8

Smith, A. J. (1990). Corporate Ownership Structure and Performance. Journal of Financial Economics, 27(1), 143-164. http://dx.doi.org/10.1016/0304-405X(90)90024-T

Spiess, K. D., \& Affleck-Graves, J. (1999). The Long-Run Performance of Stock Returns Following Debt $\begin{array}{lllll}\text { Offerings. Journal of } & \text { Financial } & \text { Economics, } & 54(1), & \text { 45-73. }\end{array}$ http://dx.doi.org/10.1016/S0304-405X(99)00031-8

Tewari, M., \& Ramanlal, P. (2010). Is the Put Option in U.S. Structured Bonds Good News for Both Bondholders and Stockholders? International Research Journal of Finance and Economics, 52(1), 50-59.

Titman, S., \& Wessels, R. (1988). The Determinants of Capital Structure Choice. Journal of Finance, 43(1), 1-19. http://dx.doi.org/10.1111/j.1540-6261.1988.tb02585.x

Vu, J. D. (1986). An Empirical Investigation of Calls of Non-Convertible Bonds. Journal of Financial Economics, 16(2), 235-265. http://dx.doi.org/10.1016/0304-405X(86)90062-0

Warga, A., \& Welch, I. (1993). Bondholder Losses in Leveraged Buyouts. Review of Financial Studies, 6(4), 959-982. http://dx.doi.org/10.1093/rfs/6.4.959

White, H. (1980). A Heteroskedasticity-Consistent Covariance Matrix Estimator and a Direct Test for Heteroskedasticity. Econometrica, 48(4), 817-838. http://dx.doi.org/10.2307/1912934 